
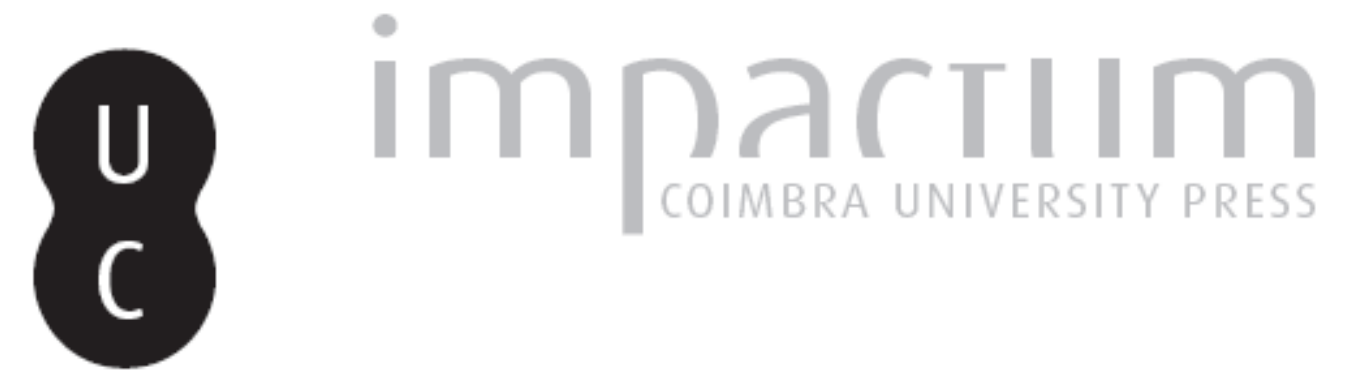

\title{
Eurípides, o mais trágico dos poetas (V)
}

Autor(es): $\quad$ Silva, Maria de Fátima Publicado por: Associação Portuguesa de Estudos Clássicos; Instituto de Estudos

URL $\quad$ URI:http://hdl.handle.net/10316.2/30465

DOI: $\quad$ DOI:http://dx.doi.org/10.14195/0872-2110_49_2

Accessed : $\quad$ 26-Apr-2023 12:55:21

A navegação consulta e descarregamento dos títulos inseridos nas Bibliotecas Digitais UC Digitalis, UC Pombalina e UC Impactum, pressupõem a aceitação plena e sem reservas dos Termos e Condições de Uso destas Bibliotecas Digitais, disponíveis em https://digitalis.uc.pt/pt-pt/termos.

Conforme exposto nos referidos Termos e Condições de Uso, o descarregamento de títulos de acesso restrito requer uma licença válida de autorização devendo o utilizador aceder ao(s) documento(s) a partir de um endereço de IP da instituição detentora da supramencionada licença.

Ao utilizador é apenas permitido o descarregamento para uso pessoal, pelo que o emprego do(s) título(s) descarregado(s) para outro fim, designadamente comercial, carece de autorização do respetivo autor ou editor da obra.

Na medida em que todas as obras da UC Digitalis se encontram protegidas pelo Código do Direito de Autor e Direitos Conexos e demais legislação aplicável, toda a cópia, parcial ou total, deste documento, nos casos em que é legalmente admitida, deverá conter ou fazer-se acompanhar por este aviso.

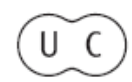




\section{Boletim de}

\section{Estudos Clássicos}

Associação Portuguesa de Estudos Clássicos Instituto de Estudos Clássicos

Coimbra

Junho de 2008 


\section{EuríPIDES, o MaIS TráGico dos PoEtas (V)}

\section{O cidadão desiludido em busca de um ideal}

Apesar de profundamente crítico do processo por que Atenas passava nesta segunda metade do séc. V a. C., em termos políticos e sociais, Eurípides não deixou, mesmo assim, de rasgar um raio de esperança e de futuro. Esse retratou-o em almas jovens e delicadas, por essas mesmas características tendencialmente femininas, as únicas capazes ainda de um gesto de generosidade magnânima. E que maior generosidade pode um ser humano demonstrar do que aquela que equivale ao desprendimento da própria vida? São vários os exemplos euripidianos destas figuras - Macária em Heraclidas, ou Meneceu em Fenícias representando exemplos expressivos. Mas nenhum, dentro das peças conservadas, tem a amplitude que é dada ao caso de Ifigénia, a cujo sacrifício o poeta dedicou uma peça completa, a Ifigénia em Áulide.

Em vez de um adivinho, a revelação da exigência de morte é agora verbalizada perante o público pelo próprio pai da vítima, Agamémnon, o chefe supremo dos Aqueus em Áulide, na iminência da partida para Tróia. O oráculo que o submerge - a exigir-lhe o sacrifício de Ifigénia em troca do direito de partir - atinge-o não tanto como um castigo divino, a punir uma imprudência ou excesso; é antes o preço cobrado a um homem poderoso pelo mais ousado dos seus projectos; tem portanto motivos essencialmente políticos. E não se trata, mesmo neste plano, de uma situação exigente, como a de salvar uma comunidade em perigo, mas sim de satisfazer um sonho de poder e de ambição. Logo o dilema de Agamémnon, que se lhe coloca sobretudo num plano pessoal, divide-o entre o amor de pai pela sua primogénita, a preferida entre os seus filhos, e o orgulho do chefe que teme pelo prestígio da sua autoridade.

Revestido de um poder incomportável para a sua natureza fraca e hesitante, o Atrida divide-se em reacções contraditórias, de acordo com as pressões externas que o vão condicionando. Primeiro é Menelau, também ele por dentro do segredo do oráculo, que lhe vence a relutância e o força a atrair a vítima ao acampamento com uma falsa promessa de casamento; 
depois a revolta íntima de um pai, estimulada pela insónia, que o leva a retroceder perante o horror que lhe é exigido; por fim um reencontro violento entre os dois irmãos, que vem revelar a debilidade e insegurança que dão corpo ao 'herói' de Micenas. Mas é deste carácter invertebrado que depende a sorte de Ifigénia.

Uma simples carta tresmalhada colabora com a necessidade de decisão, trazendo a vítima a Áulide, à própria armadilha tecida pelo progenitor; com ela chegam a mãe, Clitemnestra, e o irmão, Orestes, muito criança ainda, para o que parece ser uma festa de família, os esponsais da primogénita da casa de Micenas. Reabrem-se para Agamémnon todas as tormentas; como encarar as fatais recriminações de Clitemnestra? Ou a emoção que não deixará de lhe causar a fragilidade atemorizada de Ifigénia? Ou os gritos, inconscientes ainda, mas assustados, de Orestes ao colo da mãe?

Uma última e imprevista mudança de atitude em Menelau, expressa por uma estranha palavra de capitulação e desistência, qualquer que seja o seu motivo íntimo, tem pelo menos uma intenção dramática clara: a de deixar a decisão final, por inteiro, nas mãos do senhor de Micenas, pai de Ifigénia. E ei-lo que decide, com a teimosia dos fracos, pelo sacrifício como por um desfecho inevitável.

O grande climax da peça acontece no momento que aproxima pai e filha, carrasco e sua vítima. A dificultar ainda mais a tensão da cena, Ifigénia comporta-se com a espontaneidade sincera de uma filha amada, que, depois de uma longa ausência, reencontra o progenitor. Beijos e abraços cavam mais fundo a hipocrisia de um encontro, que esconde uma tremenda decisão: à alegria descuidada da vítima, que se mantém por longo tempo alheia ao destino que a espera, corresponde a crueldade que resulta do facto de aquele em quem ela deposita uma confiança cega ser também o seu carrasco.

Desfeito o equívoco por intervenção de um velho servo no segredo da cilada, a decisão resultará de uma cena profundamente patética, em que os seus pais discutem, perante o olhar apavorado da jovem, da sua vida ou morte. De rosto no chão, os olhos baixos, a sustentar nos braços o pequeno Orestes, uma nova Ifigénia, sofrida, assiste a este tribunal improvisado. Desmascarado agora nas suas ocultas e mesquinhas intenções, por uma Clitemnestra impiedosa, Agamémnon tem ainda de escutar as súplicas da filha, a recordação de afectos nesta circunstância estranhos e espinhosos. Porque profundamente humana, Ifigénia não adere de imediato a uma condenação. Naturalmente apegada à existência, ela reage e recusa a morte. Mas a tudo Agamémnon resiste, com o argumento da responsabilidade do 
chefe, escondendo objectivos claramente pessoais, sob a capa mais nobre dos interesses e da segurança da Grécia. Porque tardia na ponderação que o vimos fazer, esta preocupação não parece mais do que um argumento para dar uma capa de nobreza ao que é, afinal, um crime.

Mas eis que Ifigénia, perante vagos movimentos de defesa que se vão gerando em sua volta, desperta para o martírio e para a heroicidade que ele exige. Às palavras fictícias, ela opõe razões de generosidade e de ideal; nos argumentos falsos com que seu pai defendia uma guerra de ambição, ela descobre um objectivo superior ao simples encanto de viver. No cadinho da generosidade intocada de uma alma jovem, por milagre de um amor incólume pela pátria, ambição transforma-se em altruísmo, falsidade no brilho de uma sinceridade sem medida. A Ifigénia cabe, portanto, a glória, que só uma verdadeira arête proporciona; como são raras e profundamente expressivas as palavras com que exprime a doação da própria vida, saídas de uma adolescente como lição suprema à responsabilidade dos cidadãos.

\section{Ifigénia em Áulide 1375-1386

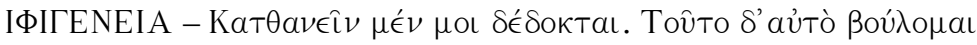

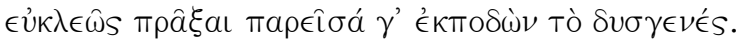

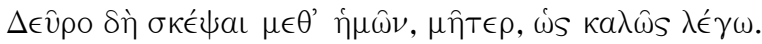

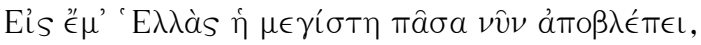

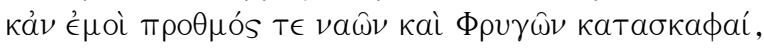

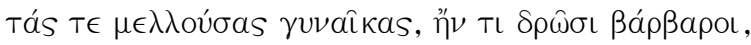

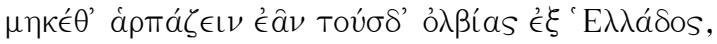

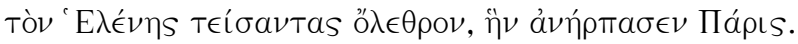

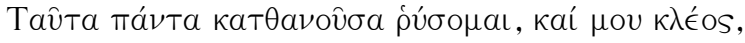

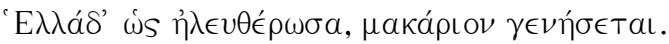

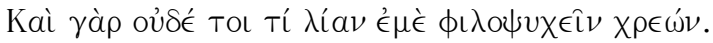

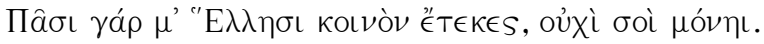

Morrer é, para mim, uma decisão tomada. Mas essa mesma morte quero convertê-la em glória, redimida de qualquer toque de mesquinhez. Ora considera comigo, mãe, como tenho razão. É sobre mim que essa imensa Grécia, toda ela, tem os olhos postos neste momento, é de mim que depende a partida da armada, a derrota dos Frígios e a sorte futura das mulheres. Os bárbaros, mesmo se o pretenderem, não terão como raptá-las do solo venturoso da Hélade, depois de terem expiado a perda de Helena, raptada por Páris. São estas as infelicidades que a minha morte evitará; assim a 
fama que ganho de libertadora da Grécia será para todo o sempre abençoada. Por isso não posso agarrar-me demais à vida. Foi para a Grécia inteira que me deste à luz, não apenas para ti própria.

M. F. S. S. 